\title{
Diversions: Obstacles for Undergraduate Students when Applying for Internship Positions Online
}

\author{
Clarisse Halpern1, Bruno Halpern² \\ ${ }^{1}$ College of Education, Florida Gulf Coast University, Fort Myers, United States \\ ${ }^{2}$ College of Arts and Sciences, Florida Gulf Coast University, Fort Myers, United States \\ Email: clari_halpern@hotmail.com, brunohalpern@gmail.com
}

How to cite this paper: Halpern, C. and Halpern, B. (2018) Diversions: Obstacles for Undergraduate Students when Applying for Internship Positions Online. Open Journal of Business and Management, 6, 165-182.

https://doi.org/10.4236/ojbm.2018.61011

Received: December 15, 2017

Accepted: January 26, 2018

Published: January 29, 2018

Copyright $\odot 2018$ by authors and Scientific Research Publishing Inc. This work is licensed under the Creative Commons Attribution International License (CC BY 4.0). http://creativecommons.org/licenses/by/4.0/

\begin{abstract}
The objective of this research was to investigate how the decision of Brazilian university students to enroll (or not) in internships' selection processes would be affected by the form and content of the ads published in social media. Thus, a qualitative research was carried out through a multiple-case study. Data were collected in semi-structured interviews via Skype, as well as direct observations of eight individuals. The category Diversions presented the most relevant results shedding light as to how the interviewees' focus was shifted while searching for internship positions during their interviews. The title refers to how distractions make students stray from their intended search for internship positions. Instead, social media exerts a sort of magnetism that is more powerful than recruiting posts and ads, attracting their attention away from internship openings search, making them secondary. In conclusion, diversions were found to become obstacles for undergraduate students when applying for internship positions online.
\end{abstract}

\section{Keywords}

E-Recruitment, Social Media, Internships, Facebook, Employment Websites

\section{Introduction}

In the last decades, the field of Human Resource Management (HRM) has undergone significant changes due to the introduction of information and communication technologies (ICTs) in organizational processes. In fact, the Information Era accelerated some organizational processes while excluded others considered less efficient [1]. The use of technologies in HRM became particularly palpable in the last 20 years when organizations started to conduct recruit- 
ment and selection processes online to fill job and internship positions as fast as possible to ensure their market competitiveness. At the same time, individuals became more interested in searching for positions online, increasing competition among organizations and outsourcing companies in recruiting potential candidates, and ensuring their subscription to selection processes [2]. Also, social media has increasingly and progressively gained preference among candidates searching for opportunities online as well as a mean of communication between them and the organizations [3]. In fact, the use of the internet in people's daily lives and corporate recruiting confirmed the Reference [4]'s prediction that the recruiting industry would become fully online. Online recruiting became more accessible for applicants, and website navigation more user-friendly [5] and easier, thus, increasing the appeal of online job ads [6]. Online recruitment became one of the most advanced systems and is extensively used in all major organizations [7]. As a result, there was a shift in the way people apply for jobs and internship positions that were adapted to an online praxis and environment that virtually anyone could do it [8] [9].

Therefore, online recruiting has become more effective to a target audience comprised of Millennials, individuals that were born after the 1980s and who are best candidates for internship and trainee placements through online recruitment strategies and processes [10]. In general, these individuals are more educated than those of previous generations, highly skilled users of ICTs, and familiarized with the world of social media. They have also been considered the first digital natives, in other words, "native speakers" of the digital language [11], often concentrating their social and professional activities and relationships on online settings. Indeed, Millennials have experienced from early age the intense ICTs transformations, as well as the emergence of web 2.0 that allowed users to become co-creators of content and interaction on the network [12] [13] [14] [15]. For that reason, members of this generation are more susceptible to entering the labor market via the internet.

While candidates for internships strive to meet the requirements for being admitted to such positions, organizations and recruiting teams compete for the attention of potential candidates employing innovative techniques to attract their interest and ensure their application to recruitment and selection processes [16] [17]. Thus, marketing strategies are considered key to the recruitment process. Regardless of being in the form of ads in specific websites, institutional videos and information spread on social media, or specially designed emails, among other strategies, the aim is to involve and attract potential candidates to the organization [17] [18]. Therefore, considering the importance that marketing strategies have acquired in the recruitment process, in the present study the researchers examined how Brazilian undergraduate students relate to social media when they look for internship positions online.

\section{Recruiting Undergraduate Students Online}

Traditionally, throughout the twentieth century, recruiting was carried out through 
advertisements published in newspapers, magazines, corporate bulletins, posters spread in unions, professional associations, and universities, or even on radio calls and television, as they reached a large number of potential candidates [19]. However, the advent of the internet has brought changes to all dimensions of people's lives (de) constructing old paradigms of communications and relationships. In the corporate realm, it provoked profound changes, establishing a new and closer form of company-client relationship, different from the previous one restricted to satisfaction surveys and contact at the moment of purchase [20]. The new possibilities that emerged with ICTs have proven that the traditional mechanisms of dissemination of information were doomed to decline or extinction. Thus, given the speed of the circulation of the information supplied by ICTs, the conventional means of communication have become incompatible with the market demands. Progressively, it requires more creativity in its design and the content of the message to compete with the dynamism of the images displayed on the portable screens that can fit in any purse or pocket.

So, recruiting online has demanded changes of strategies to attract the target audience's attention, as well as it has required a change in the HR professionals' profile, requiring their mastery of the use of marketing tools and skills [17]. For that reason, from here on, we will redirect marketing concepts that are typically applied to consumers, products, and services to a context in which internship candidates are considered to be "consumers of selection processes" due to the similarities between recruiting efforts and those of attracting consumers to buy products and services.

Hence, the marketing communication strategies applied to our study are mainly advertising, direct marketing, and social media with the aim to inform students about internship positions available in organizations to persuade them to enroll in their respective selection processes. Reference [21] explained that advertisements aim to raise awareness and generate knowledge on the target audience about a product, service, or brand, to arouse sympathy, conviction, and preference among consumers. Similarly, advertisements in recruitment processes for internships aim to inform students about an organization, emphasizing its positive attributes to raise their desire to work for it, impacting on their preference in choosing to apply for its selection process. Reference [22] found that repeated exposure of objects to individuals leads to increased ratings and positive perceptions about them. So, the more a student is acquainted with a company, the more positive will be his/her response to recruiting calls [23] and the higher the attractiveness rate to participate in their selection processes [24]. Therefore, companies should come up with different recruiting strategies to consolidate the memory of their positive attributes in the minds of potential candidates, leading them to apply to the selection processes.

To that end, Reference [21] maintained that advertisements must contain specific icons, symbols, images, and languages to attract the interest of the target audience. In the case of recruiting undergraduate students for internships, advertisements and recruiting calls must contain elements with which Millennials 
will identify themselves based on characteristics related to this generation long-described by scholars. Therefore, anything that inspires open-mindedness, innovation and creativity, entrepreneurship, desire of taking responsibilities and seeking new experiences, face challenges and change, have autonomy, flexibility, and offer quality of life [12] [13] [25] [26] [27] [28] [29] should attract members of this generation to selection processes.

Direct marketing plays an essential part in recruiting students online because it uses personalized e-mails [21] [30] to reach potential internship candidates. It is a strategy that is favored by candidates' information and resumes stored in large databases. Thus, it allows for customization in which the content of messages can be adjusted according to the position being advertised, serving the desired niche [30] and facilitating HR professionals' tasks. Also, it is particularly useful to attract passive candidates, that is, those that are not actively or intentionally seeking for internship opportunities and that is informed about opening positions via alerts sent by e-mail [31]. Considering that members of the Millennials generation are more prone to centralize every aspect of their lives online, being constantly connected, direct marketing strategies can be beneficial to capture their attention so they can become candidates in selection processes for internship positions.

The use of the internet in recruiting strategies demand the construction of websites and social media pages that will attract the attention of potential candidates to persuade them to apply to selection processes. Therefore, they must be easy to navigate [32], available year-round, 24 hours a day, seven days a week, allowing instant communication between candidates and companies [18]. Organizations may use the online setting to increase their visibility and popularity, showcase and monitor their reputation among social media users [33]. Also, organizations can take advantage of students being frequently connected online to influence their perceptions about the organization through advertisements displayed on the internet. In effect, potential candidates will apply for the company's selection processes.

In addition, social media has become one of the most powerful recruiting tools and a strategy that increases interaction and enables the sharing of information between companies and potential candidates [34]. In fact, $92 \%$ of individuals with profiles on social media are Facebook users [35], which is why $84 \%$ of organizations currently use social media for recruiting. Also, $82 \%$ of passive candidates are found through social media [36] facilitating HR professionals' recruiting efforts online.

Indeed, groups and pages designed to recruiting strategies are widespread on Facebook, reaching thousands of members and followers. In such cases, not only HR professionals but most frequently regular users advertise the positions as means of promoting networking among participants. So, when a user becomes part of one of these groups and follows one of these pages on Facebook, daily posts become available with jobs and internship positions ads, as well as information about the labor market of that segment. Therefore, due to Millennials' 
familiarity with the internet, they are usually more prone to navigate on social media pages, blogs, and websites more naturally and more frequently [12] [26] [28] [37]. Consequently, those medias become the ideal setting for recruiters to find potential undergraduate students searching for internships, and attract their interest of becoming part of the organization.

Besides, the fact that social media contain relevant data about their users including personal information and preferences, demographic and geographical characteristics, among many others, favors the creation and dissemination of information to the desired audience on those medias. In fact, when a company has a page on social media, it can choose its target audience so that its ads and content are sent directly to them [38]. Thus, Facebook, for example, enables the company to segment the universe to which its recruiting calls will focus [39] delimitating the target audience's user profile by age, education, location, among others, to advertise their internship positions. Therefore, those elements can highly contribute to HR professionals when designing strategies on social media to recruit undergraduate students for internship positions.

\section{Methods}

A qualitative research was conducted through the multiple-case study method [40] to value the subjects' experiences allowing that information from one case could complement those of others, favoring a complete analysis of the data through the logic of replication [41]. The logic of replication implied the construction of a robust theoretical framework that allows the generalization of new cases [40] [42]. For this reason, the multiple-case study method admits theoretical generalization to predict similar phenomena. In fact, while research based on surveys lead to statistical generalizations, multiple-case studies are based on analytical generalizations, that is, the researcher generalizes particular results to a broader theory [40].

Data collection was carried out through direct observations and individual interviews because, when combined, they reveal the meaning of the experiences for the individuals [43]. When conducting direct observations [44], the researchers aimed to capture the maximum of information relevant to the context of the research on site, that is, on the setting that the event occurred in real time. Thus, it included individuals' situations, and behaviors, ensuring a more prolonged and detailed monitoring of the experiences [40]. The individual open-ended interviews [45] helped the researchers know the opinions, beliefs, interests, as well as situations experienced by the interviewees [46]. Data were collected in the environment in which the study of the phenomenon naturally occurred [47], that is, in the interviewees' homes via Skype.

The subjects' choice was based on the proposed profile, that is, undergraduate students seeking internship positions. However, the number of subjects was not decided a priori, but defined throughout the research, according to the researchers' reflections and analysis. In other words, while data were collected and analyzed, it was possible to determine if the results satisfied the research objectives. 
Therefore, the researchers understood that the number of cases (subjects) seemed to be sufficient, reaching the so-called theoretical saturation, which is, when new data do not add relevant information to the research [48].

One of the researchers published a post on Facebook inviting undergraduate students to participate in the study. Fourteen individuals volunteered, though eight became available to be interviewed and observed: five undergraduate students and three recently graduated. Although the post was clear about asking for undergraduate students as volunteers, the researchers decided to include the newly graduated ones because they were eager to share their experiences as candidates to internship selection processes. Also, even though the research call required that the interviews should take place at the person's house or university, some volunteers asked if they could occur via Skype. Thus, eight individuals were observed and interviewed via Skype, with an average duration of 30 to 90 minutes.

The interviewees were studying Civil Engineering, Psychology, and Journalism. The others had just graduated in Communication, Advertising, and Marketing. Their ages ranged from 21 to 24 years old. Although two of the recent graduates had already had internship experiences, at the time of the survey, they were unemployed. All four undergraduate students were taking internships at the time of the interview, but three were in search of new opportunities.

During the interviews, the subjects were told to comment on their decisions to choose (or refuse) to navigate in specific recruitment websites, media, and social networks, in the course of their internet inquiries. The interviewees were instructed to point the positive (or negative) aspects related to the form and content of the ads that attracted them. They were oriented to navigate freely in search of internship positions as if they were alone so that the researchers could capture their movements on the network realistically.

As the interviewees chose to use specific domains online, as well as they decided to know more about an internship position, the researchers asked them about the reasons that led them to make each decision. So, the interviews were conducted spontaneously based on the subjects' choices and opinions [40]. The spontaneous nature of the interviews required that the researchers were aware of new elements that could appear and be added to their findings during the process. Also, the results were recorded, including personal comments from the researchers, constituting a descriptive and reflective stage of the research [49].

Interviewees signed an informed consent authorizing their participation in the research that would guarantee confidentiality regarding their identities and their right to non-response or interrupt their participation. Also, they consented that the interviews and observations were recorded and, later, transcribed [47]. The institutional credentials of the researchers, the objectives of the research, and the transparency of the procedures were clarified when the consent form was presented [44] [47]. To ensure the participants' confidentiality and anonymity their names were changed into pseudonyms. 
Data interpretation was carried out using the Peircean abduction [50] of the particular categories that emerged in the discourse of the subjects. Thus, there were no pre-established categories. The method of abduction analyzed data in Communication developed by [51] which allows the creation of an interpretive framework. Also, this method organizes the data and reveals pieces of evidence which may not be noticeable in the subjects' interviews.

\section{Results}

The findings revealed five main categories. This article focuses on presenting one of them which was named Diversions. The research found that the interviewees were often distracted, putting the search for internship positions in second place. Instead, they prioritized other activities. Most of them engaged in activities such as forwarding messages, texting through Whats App and Messenger, scrolling their timelines on Facebook, liking, commenting, and sharing posts, downloading videos, movies, and files, in addition to checking their emails and tweets on Twitter. They interrupted the interviews to speak (in person) predominantly with their mothers, as well as other relatives. Thus, Diversions is a category that unveils a peculiar attitude of the interviewees as to how their focus shifted during the interviews, expressed in the distractions that led them to stray from their search for internship positions to do other things, particularly online. Following are some of the interviewees' statements about the websites and social networks they kept open during the interviews. It is interesting to note that they checked these media several times, indicating an intense connection with them:

I have some open tabs, like esoteric sites, Facebook, Messenger. I have my cell phone turned on because of WhatsApp. I $m$ also reading Harry Potter's fanfictions. And Twitter is also open. (Fred, 24, recently graduated).

I have many tabs open! Netflix, my email, downloading videos and, oh, Facebook, of course [laughing]! I always open many tabs! (Thiago, 23, recently graduated).

I $m$ checking my email, and my Facebook is open. I $m$ always checking it out, taking a look at the updates and notifications, especially on Facebook [laughing]. (Luana, 21, Psychology major).

Wow! [laughing] $P m$ surprised to see that I have so many tabs open at the same time! Facebook, email, Twitter, MANY [emphatic] open tabs. I m downloading movies too. (Gabriela, 23, Journalism major).

Those statements exemplify the intense interconnectivity that members of this generation have in common. The interviewees demonstrated great familiarity with ICTs, mainly with social media in general. In addition, their ability to multitask especially on the internet [12] [26] [28] [37] [52] was clear, demonstrated with the several browser tabs opened and in use during the interview.

Furthermore, despite the subjects revealing they preferred receiving internship positions' openings advertisements via e-mail, their behavior demonstrated that they center all their activities-social, personal, professional, and enter- 
tainment-on Facebook, suggesting a need to remain in a familiar setting that we called Comfort Zone. Indeed, some of them were already online on their Facebook pages before the interview started. Most of them preferred this social media as a search tool for being a Comfort Zone for entertainment, information search, and chatting. Only one respondent said that instead of looking for internship positions through Facebook groups, he preferred to find them through asking his classmates and instructors. Seven respondents demonstrated familiarity with the use of the social network, in particular, Facebook, as can been seen from the following statements:

Since $I m$ already on Facebook [laughing], the first thing to do is to look for internship positions' ads in the group. (Vitoria, 21, Journalism major).

Facebook is the first place I look for internships. In general, these recruitment websites don't show as many results as Facebook. There are so many people accessing it. For example, in this group [for internship ads] alone there are 13,000 members. So, that's the first place I look! (Gabriela, 23, Journalism major).

Facebook is my first choice, you know? [laughing] Mainly because I m familiar with it. Second, it's already open in a separate tab. Then I go to my university's webpage to look for internships as I have been doing since I started looking for internships (Thiago, 23, recently graduated).

Clara and Julia also expressed that Facebook embodies a comfort zone where one has "everything" he/she needs when looking for internships, instead of exploring other sites online:

Facebook and Google are all I need; they have everything. It's kinda funny, but I actually think it's easier to find things on Facebook. I type "communication internship positions," and I skim through the groups. (Clara, 23, recently graduated).

I don't look elsewhere! What for? Facebook has everything! (Julia, 22, Journalism major).

Subjects' statements revealed that they were very familiar with ICTs, online media, and social networks. During the interviews, not only did they keep many browser tabs opened, but they also rapidly migrated from one site to the other without carrying out a more accurate and careful analysis. This behavior suggests that they were more prone to experiences that could connect to their immediate interests than to invest in applying for internship positions. Gabriela's comments may indicate to which extent the notifications require a prompt response, requiring all her attention:

I $m$ downloading another $T V$ show, checking my emails and now $1 \mathrm{~m}$ going through my tabs to click on all notifications [on Facebook and Twitter]. I mean, I do everything at the same time! Don't mind me; it's just that I have an issue with notifications. When one [notification] pops-up, I MUST [emphatic] check it out. I MUST [emphatic] see it! (Gabriela, 23, Journalism major).

Interviewees' reactions suggested that they have an agile, impatient, and even agitated way of behaving online. In effect, they found it hard to tolerate extended 
applications in recruiting websites that would deter them from being free to enjoy other activities online, that is, those considered more pleasant than internship application:

I have to log in every single time. It's very annoying! This recruiting site doesn't save my information! So, I avoid going there since it will demand the log in every time I visit it. If Facebook or Twitter or YouTube did the same, I wouldn't check those websites as often either. It's kinda lazy of me, I reckon! If there were a simple tweak to the website, allowing the user to remain logged in, it would make it so much easier. Also, their website is quite clunky. I don't think it's very intuitive, and it's quite all over the place. (Fred, 24, recently graduated).

When studying surveillance through ICTs, Reference [53] highlighted that immediacy has come to govern how Millennials understand and negotiate their internet experience, outweighing any other concerns the participants could have had. Although there has been an expansion of online recruitment with the multiplication of specialized websites [2], the interviewees showed little interest in them. Conversely, Facebook was their primary choice to search for internship positions, feeling "at home" to provide the academic and professional information they needed.

Oh, Facebook is way easier! I can access it on my phone anytime. I wake up, and $\mathrm{I} m$ already there. Also, Facebook groups are good because they are almost like a word of mouth of everyone in my College. It makes me feel more comfortable knowing that whatever is being shared has to do with the guys I follow, with my friends and my interests. (Julia, 22, Journalism major).

It's so much easier! If you' re already on Facebook, all the time, you end up seeing the ads. Why should I look elsewhere? Everyone I know is on Facebook. One can access it from all kinds of devices, literally from everywhere. So, it's very effective! Also, Facebook gives me what I need. I can find internship opportunities; I can be closer to my Professors that often offer curricular practical training, things I really need to learn. I think Facebook handles all of that pretty well. (Luana, 21, Psychology major).

$C$ mon, I $m$ on Facebook every single day. Actually, I m on Facebook all the time! It's good for practically everything. I can watch videos, news, message people and even search for internship positions. (Fred, 24, recently graduated).

Facebook is a fascinating tool for everyone looking for an internship, really! You can find awesome companies offering positions! (Vitoria, 21, Journalism major).

I do search on Google and Facebook. But my preference is Facebook, for sure! It's easier to find everything. My main criterion when choosing a group to join in is always the number of members that are on it. I feel it gives more credibility to it. (Clara, 23, recently graduated).

Only one of the interviewees, Ronaldo, was focused on the interview without opening any website or social media. When asked if he was doing any other activity on the internet, he reported that he had no interest in looking at other non-recruiting websites. 
Therefore, the category Diversions stood out not only because it could be present in almost all the interviews, but also because of the way and intensity that these kinds of distractions occurred. The interviewees' statements revealed that responding to notifications was a priority over looking for and applying to internship positions, regardless of being instant messages, posts on Facebook, online request for events, among many others. It must be stated that some actions could not be captured in speeches, since it was common for the interviewees to continue to describe their reasoning and opinions about each website, internship position, or its advertisement, while were looking at their Facebook wall, status updates from their friends, commenting and sharing posts, videos, or photos to name a few. When asked how they were able to keep their eye on a website or ad while rolling Facebook pages with "news," subjects said they were able to do multiple things at the same time, as elucidated by Fred:

I can do everything at the same time. I can talk to you while $1 \mathrm{~m}$ on Facebook. It is as if $\mathrm{Ym}$ looking at everything and at nothing at the same time! (Fred, 24, recent graduate).

The importance of this statement lies in the fact that members of the Millennials generation tend to be more interconnected with the rest of the world due to their familiarity with the ICTs. Also, it relates to their ability to deal with a significant amount of information at the same time and to be prone to multidisciplinary interests [12] [26] [28] [37]. Also, it exemplifies the paradox of being online because being connected to "everything" and "nothing" at the same time seems to indicate an existential void to which internet users are subjected to and submerged, a striking feature of the modern-day life presented by Reference [54]. Also, it proved the fugacity of the online connections between subjects and the websites they visited. Therefore, each time the interviewees closed a tab of their search for internship positions, it revealed that their interest was not in the search, but instead of being connected to their interests. Also, as social media constitute a new paradigm of interconnection between people [55], it explains why the subjects' relationship to those medias were more involving and engaging than the content of internship positions' ads themselves. In other words, the power of being connected to social media was stronger to the interviewees than their content.

\section{Discussion}

There are many reasons why candidates can be distracted when faced with online recruitment, named Diversions, deterring them to focus on the experience of searching for openings and applying for internship positions online. On the one hand, Facebook, Twitter, YouTube, and other social media may distract and entertain them up to the point that one may not succeed to accomplish the application itself. On the other hand, it is undeniable that the web-based recruiting system and online application enlarged recruiting efficiency, for being user-friendly and for providing vast information about job and internship posi- 
tions, widely used by both recruiters and job seekers across the world. Scholars have pointed out that users are more within reach of recruiters thanks to the ample possibilities of recruitment offered by the media and social networks [3] [16] [17] [18]. Nevertheless, throughout the interviews, it became evident that despite the expansion experienced by online recruitment in recent years and the incorporation of marketing strategies employed to capture the attention of internet users, the virtual environment was more engaging than the content of the internships openings per se. In fact, online social networks became a new paradigm of interconnection between people [55].

If one can be distracted during the application process online, conversely, many aspects contribute for a person to stay focused on recruiting online systems. The websites greater usability, style, content, and speed play a significant effect on users' attitudes and intentions [5]. The vastness of possibilities, paths, and relationships on social media causes individuals to be swept away by the multisensory dynamics of the internet and magnetized by the propagandistic actions.

Besides, social network sites (SNS), like Facebook, attract users because they enable potent social capitals. One of the first definitions of social capital was proposed by Reference [56] as "the aggregate of the actual or potential resources which are linked to possession of a durable network of more or less institutionalized relationships of acquaintance and recognition (p. 51)." More than ever, Facebook provides its users with tools that increase their abilities to enlarge their social networks, consequently, producing a significant context that allows for social capital exchanges [57]. Moreover.

"Facebook serves as a powerful platform for not just asking for help but also providing help, gaining access to information, coordinating with one's Friends, and accessing Friends of Friends through networks ties. Each of these processes contributes to the complex, multi-faceted, and rich tapestry of interactions that help people feel that they have access to important social resources." ([58], p. 1119).

In addition, it could be seen that the interviewees' statements indicated the intense interconnectivity, one of the characteristics that make up the members of Millennials' generation. However, it should be argued if Diversions would evidence a "lack of focus" or a "multi-focus." Besides, this behavior seems to be peculiar to Millennials who are believed to have different attitudes related to their work and careers, mainly when compared to their older co-workers [59]. Nevertheless, it must be taken into consideration that the matter "Millennials" should move beyond generational stereotyping, like Reference [60] had cautioned in her studies, chiefly to a more accurate, context-sensitive advice about cross-generational communication.

Another aspect that should be emphasized is that the interviewees expressed that their desire to be recruited can be ephemeral. Rather than being recruited or not, they aimed to be connected to the media more than being recruited as demonstrated by how promptly they interrupted the search for internship posi- 
tions to post, react to content they saw online, send messages, indicating that they were more attracted by other activities, mainly those displayed on Facebook.

The interviewees revealed that the search for internship positions transcended the form and content of the advertisements. Reference [61]'s assertion that the medium is the message helps to understand the primary relationship between the subjects and the media, particularly with Facebook. So, they showed that they have a more significant connection with the medium, that is, with social media than with online internship postings in e-recruitment websites, or rather with the message because the medium itself has a unique meaning.

In effect, this research confirmed that the interviewees actually "lost" their focus, distracting themselves with other topics of interest. Being "plugged" into multiple links can be equal to having no real connections at all, evidencing the fugacity of this sort of relationships. The category Diversions may be signaling the actual priority of these individuals and, therefore, they would not mean diversion or a sort of deviation. Conversely, the search for internships would be relegated to a secondary plane. Apparently, their first interest would be to remain online and connected, neglecting other alternatives constantly. Therefore, one can be connected to "everything" and, paradoxically, to "nothing" at the same time, indicating that internet users may experience an existential void and shallow relationships. This is a remarkable trait of the software-based modernity which became "light" and "liquid," transforming the human condition. "Liquidity" and "fluidity" are metaphors used by Reference [54] to express the nature of the present phase in the history of modernity. Modernity's essential attribute from which all other characteristics follow is the changing relationships between space and time. As Reference [54] stated, "Velocity of movement and access to faster means of mobility steadily rose in modern times to the position of the principal tool of power and domination (p. 9).”

Nowadays, power has become exterritorial, not restrained by space or controlled by a central facility like the Panopticon - an institutional building design for a prison - a metaphor used by Reference [62] to illustrate the operation of power and surveillance in contemporary society. In between the lines lies the matter of power of influence. In other words, how human resources will capture one's attention in a noisy environment up to the point that a person will become an applicant after a click of the mouse. "The study of power on social media is complex as attention is relational, temporal, and contextual. [...] Power becomes fluid as it is assigned and reassigned through interactions on social media" ([63], p. 1).

People share messages on a social network but can only pay attention to a portion of the information they receive. Therefore, online recruitment is compelled to dispute for peoples' attention with an infinite number of means that are continuously available. Usually, information travels from an individual to their immediate social circle and then quietly fades away [64]. As Reference [63] pointed out, “The problem, though, isn't having a voice. It is being heard. The 
inconvenient truth about social media is that most tweets, photos, and videos simply wither in the perpetual onslaught of information (p. 1).”

\section{Conclusion and Recommendations}

The researchers concluded that their study had achieved its primary goal, that is, of understanding how Brazilian undergraduate students relate to social media while looking for internship positions online. The objective was achieved insofar as the multiple-case study method, applied through open-ended individual interviews and direct observations of the subjects responded the question as to whether their decision to enroll (or not) in internships' selection processes would be affected by the form and content of the ads published in social media.

In fact, the chosen research method allowed the interviewees to expose their choices, opinions, interests, and anxieties freely, revealing the elements that responded to the research problem and the proposed objective. It should be noted that there was no significant difference between the narratives of the interviewed students and the ones that had just graduated because they belong to the same generation and age group, as well as they shared the same interests, behaviors, and language.

The limitations of this study suggest that further investigations should be carried out with other groups, with different demographic characteristics, for example. The researchers also recommend studies that could compare face-to-face observations with the interviews that were carried online via Skype. Perhaps the physical presence of the researchers along with the interviewees could bring valuable additional information to new investigations.

Also, it is possible that there was a bias on the part of the researchers regarding their final decision to interview the subjects via Skype because they were too part of the same generation that feels familiar with having most aspects of their lives handled online. Therefore, the lack of absolute neutrality in the way the researchers' conducted their studies, they accepted the subjects' request to be interviewed online for a matter of practicality. Consequently, the researchers agreed to be part of the subjects' ethos online in which ephemeral, accelerated, and disposable relationships prevail.

The results indicated that the subjects may or may not become candidates of selection processes for internship positions, despite the marketing efforts and strategies to capture their short attention in a highly involving and engaging environment such as those of social media. The navigation became the protagonist as the recruitment of potential candidates became uncertain, at the mercy of an improbable click. Thus, the competition was not between organizations and their ads for internship positions, but rather the online environment itself, mainly Facebook wherein individuals' subjectivity is objectified and as it gained a status of real existence in their lives.

Consequently, organizations should not rely solely on using recruiting strategies or marketing tools to capture their target audience, but rather to dispute their attention online, among news, controversial discussions, memes, photos, 
among other distractions that seem more attractive and fun than searching for and applying to internship positions. Therefore, it seems that recruiting websites need to focus on strategies on Facebook to contact and capture their audience's attention to increase the chances of application.

Indeed, the extensive incorporation of social media in people's and organizations' everyday life has enlarged the spectrum of choices and pathways, increasing recruiters' competition for candidates' restricted attention. At first, recruitment expanded with the use of social media as a tool, reaching individuals without apparent barriers. Nevertheless, obstacles have arisen, notably the dispute with other information on the internet.

"The abundance of information to which we are exposed through online social networks and other socio-technical systems is exceeding our capacity to consume it. Ideas must compete for our scarce individual and collective attention. As a result, the dynamic of information is driven more than ever before by the economy of attention, first theorized by Simon." ([64], p. 1).

In this sense, online recruiters should consider the limited attention of their target audience when designing recruiting strategies online, as well as the different degrees of influence of information spreaders [65]. Despite the advancements in marketing technology that enhanced the intrinsic quality of the information advertised, recruiting still faces the challenge to struggle for internet users' attention, particularly those of students, online while waiting for a click.

\section{References}

[1] de Carvalho, A.V., do Nascimento, L.P. and Serafim, O.C.G. (2011) Administração de recursos humanos [Humanresource Management] (Vol. 1, 2nd Edition). Pioneira, São Paulo.

[2] de Araújo, S.F. and Ramos, A.S.M. (2002) Recrutamento on-line: Estudo da percepção de utilização da internet em empresas de consultoria de recursos humanos [Online Recruitment: Study of the Perception of Internet Use in Human Resources Consulting Firms]. XXII Encontro Nacional de Engenharia de Produção, Curitiba.

[3] Duarte, J.E.N. (2011) Redes sociais e recrutamento de recursos humanos: Modelação do perfil do colaborador [Social Networks and Human Resources Recruitment: Modelingthe Profile of the Employee]. Master's Dissertation, Universidade do Porto, Portugal.

[4] Edgley, K. (1995) The Best Job in the World May Be One Click Away. The Times, No. 11, October.

[5] RoyChowdhury, T. and Srimannarayana, M. (2014) Applicants' Perceptions on Online Recruitment Procedures. Management and Labour Studies, 38, 185-199. https://doi.org/10.1177/0258042X13509737

[6] Braddy, P.W., Thompson, L.F., Wuensch, K.L. and Grossnickle, W.G. (2003) Internet Recruiting: The Effects of Webpage Design Features. Social Science Computer Review, 21, 374-385. https://doi.org/10.1177/0894439303253987

[7] Cushway, B. (2002) The Employer's Handbook. 11th Edition, Kogan Page Ltd.

[8] Al-Khanak, S.A.K. and Mahmood, N.H.N. (2014) Factors Influence Organization Management towards Using Electronic Recruitment Strategy. Sains Humanika, 2, 
47-52.

http://www.sainshumanika.utm.my/index.php/sainshumanika/article/view/413/378

[9] du Plessis, A.J. and Frederick, H. (2012) Effectiveness of E-Recruiting: Empirical Evidence from the Rosebank Business Cluster in Auckland, New Zealand. Science Journal of Business Management, Article ID: sjbm-126, 21 p.

[10] Thomas, S.L. and Ray, K. (2000) Recruitment and the Web: High-Tech Hiring. Business Horizons, 43, 43-52. https://doi.org/10.1016/S0007-6813(00)89200-9

[11] Pyöriä, P., Ojala, S., Saari, T. and Järvinen, K. (2017) The Millennial Generation: A New Breed of Labour? SAGE Open, 7, 1-14. https://doi.org/10.1177/2158244017697158

[12] Alsop, R. (2008) The Trophy Kids Grow up: How the Millennial Generation Is Shaking up the Workplace. Jossey-Bass, San Francisco.

[13] Smola, K.W. and Sutton, C.D. (2002) Generational Differences: Revisiting Generational Work Values for the New Millennium. Journal of Organizational Behavior, 23, 363-382. https://doi.org/10.1002/job.147

[14] Sproull, L., Dutton, W. and Kiesler, S. (2007) Introduction to the Special Issue: Online Communities. Organization Studies, 28, 277-292. https://doi.org/10.1177/0170840607076013

[15] Twenge, J.M. and Campbell, S.M. (2008) Generational Differences in Psychological Traits and Their Impact on the Workplace. Journal of Managerial Psychology, 23, 862-877. https://doi.org/10.1108/02683940810904367

[16] Cappelli, P. (2001) Making the Most of On-Line Recruiting. Harvard Business Review, 79, 139-146.

[17] Finnigan, D. (2013) Recruiting Is Marketing: 4 Lessons Your HR Team Can Learn from the Marketing Department. Electronic Recruiting Exchange.

https://www.ere.net/recruiting-is-marketing-4-lessons-your-hr-team-can-learn-fro m-the-marketing-department/

[18] Nakayama, M.K., Garzieira, A. and Binotto, E. (2006) Internet: Advantages and Disadvantages in the Online Recruitment and Selection Process. In: Nakayama, M.K., Pilla, B.S. and Binotto, E., Eds., e-HR: Concepts and Practices of Electronic $H R$, Editora UPF, Passo fundo.

[19] Bohlander, G. and Snell, S. (2009) Human Resource Management. 14th Edition, Cengage Learning, São Paulo.

[20] Churchill, G.A. and Peter, J.P. (2013) Marketing: Creating Value for Customers. 3rd Edition, Saraiva, São Paulo.

[21] Kotler, P. and Keller, K.L. (2012) Marketing Management. 14th Edition, Pearson Prentice Hall, São Paulo.

[22] Ehrhart, K.H. and Ziegert, J.C. (2005) Why Are Individuals Attracted to Organizations? Journal of Management, 31, 901-919. https://doi.org/10.1177/0149206305279759

[23] Gatewood, R.D., Gowan, M.A. and Lautenschlager, G.J. (1993) Corporate Image, Recruitment Image, and Initial Job Choice Decisions. The Academy of Management Journal, 36, 414-427. https://doi.org/10.2307/256530

[24] Turban, D.B., Lau, C.M., Ngo, H.Y., Chow, I.H.S. and Si, S.X. (2001) Organizational Attractiveness of Firms in the People's Republic of China: A Person-Organization Fit Perspective. Journal of Applied Psychology, 86, 194-206. https://doi.org/10.1037/0021-9010.86.2.194

[25] Cennamo, L. and Gardner, D. (2008) Generational Differences in Work Values, 
Outcomes and Person-Organization Values Fit. Journal of Managerial Psychology, 23, 891-906. https://doi.org/10.1108/02683940810904385

[26] Huntley, R. (2006) The World According to Y: Inside the New Adult Generation. Allen \& Unwin, Sydney.

[27] Munro, C.R. (2009) Mentoring Needs and Expectations of Generation-Y Human Resources Practitioners: Preparing the Next Wave of Strategic Business Partners. Journal of Management Research, 1, 1-25.

[28] Tapscott, D. (2009) Grown up Digital: How the Net Generation Is Changing Your World. McGraw-Hill, New York.

[29] Wong, M., Gardiner, E., Lang, W. and Coulon, L. (2008) Generational Differences in Personality and Motivation: Do They Exist and What Are the Implications for the Workplace? Journal of Managerial Psychology, 23, 878-890. https://doi.org/10.1108/02683940810904376

[30] Chaffey, D. (2003) E-Marketing. In: Baker, M.J., The Marketing Book, 5th Edition, Butterworth-Heinemann, Oxford.

[31] Almeida, W. (2004) Capturing and Selecting Talent: Rethinking Theory and Practice. Atlas, São Paulo.

[32] Nielsen, J. and Mack, R.L. (1994) Usability Inspection Methods. John Wiley \& Sons, New York. https://doi.org/10.1145/259963.260531

[33] Recuero, R. (2009) Social Networks on the Internet. Sulina, Porto Alegre.

[34] Han, J. and Han, J. (2009) Network-Based Recruiting and Applicant Attraction in China: Insights from both Organizational and Individual Perspectives. The International Journal of Human Resource Management, 20, 2228-2249. https://doi.org/10.1080/09585190903239633

[35] Zappe, J. (2011) More Employers than Ever Recruit on Social Networks. Electronic Recruiting Exchange. https://www.ere.net/more-employers-than-ever-recruit-on-social-networks/

[36] SHRM Survey Findings: Using Social Media for Talent Acquisition-Recruitment and Screening. Society for Human Resource Management.

https://www.shrm.org/hr-today/trends-and-forecasting/research-and-surveys/Docu ments/SHRM-Social-Media-Recruiting-Screening-2015.pdf

[37] Erickson, T. (2008) Plugged in: The Generation Y Guide to Thriving at Work. Harvard Business Press, Boston.

[38] Shih, C. (2009) The Facebook Era: Tapping Online Social Networks to Build Better Products, Reach New Audiences, and Sell More Stuff. Prentice Hall, New York.

[39] Rocha, T.V., Jansen, C.L.S., Lofti, E. and Fraga, R.R. (2013) An Exploratory Study on the Use of Social Networks in Building Customer Relationships. Revista Brasileira de Gestão de Negócios, 15, 262-282.

[40] Yin, R.K. (2005) Case Study Research: Design and Methods. SAGE Publications Inc., New York.

[41] Cooper, D.R. and Schindler, P.S. (2003) Research Methods in the Field of Administration. 7th Edition, Bookman, Porto Alegre.

[42] Stake, R.E. (2005) Qualitative Case Studies. In: Denzin, N.K. and Lincoln, Y.S., Eds., The SAGE Handbook of Qualitative Research, 3rd Edition, Sage Publications, Thousand Oaks.

[43] Denzin, N.K. and Lincoln, Y.S. (2006) Qualitative Research Planning: Theories and Approaches. 2nd Edition, Artmed, Porto Alegre. 
[44] Minayo, M.C.S., Deslandes, S.F. and Gomes, R. (2007) Socialresearch: Theory, Method and Creativity. 26th Edition, Vozes, Petrópolis.

[45] Fossey, E., Harvey, C., McDermott, F. and Davidson, L. (2002) Understanding and Evaluating Qualitative Research. Australian \& New Zealand Journal of Psychiatry, 36, 717-732. https://doi.org/10.1046/j.1440-1614.2002.01100.x

[46] Marconi, M.A. and Lakatos, E.M. (2000) Scientific Methodology. 3rd Edition, Editora Atlas, São Paulo.

[47] Creswell, J.W. (2014) Research Design: Qualitative, Quantitative, and Mixed Methods Approaches. 4th Edition, Sage Publications, Thousand Oaks.

[48] Strauss, A.L. and Corbin, J. (2008) Basics of Qualitative Research: Techniques and Procedures for Developing Grounded Theory. 3rd Edition, Sage Publications, Thousand Oaks.

[49] Godoy, A.S. (1995) Qualitative Research: Fundamental Types. Revista de Administração de Empresas, 35, 20-29. https://doi.org/10.1590/S0034-75901995000300004

[50] Peirce, C.S. (1935) The Collected Papers of Charles Sanders Peirce. In: Hartshorne, C., and Weiss, P., Eds., Pragmatism and Pragmaticism and Scientific Metaphysics, Harvard University Press, Cambridge, Volumes V and VI.

[51] Boudon, P. (1998) Abduction and the Field of Semiotics. In: Brunel, G., Ed., Communicational Third: Communication, Legitimation, Abduction, Harmattan, Montreal, 255-284.

[52] Abrams, J. and von Frank, V. (2014) The Multigenerational Workplace: Communicate, Collaborate, and Create Community. Corwin, Thousand Oaks. https://doi.org/10.4135/9781483387741

[53] Lee, A. and Cook, P.S. (2014) The Conditions of Exposure and Immediacy: Internet Surveillance and Generation Y. Journal of Sociology, 51, 674-688. https://doi.org/10.1177/1440783314522870

[54] Bauman, Z. (2000) Liquid Modernity. Polity, Cambridge.

[55] Oliveira, E.R. and Telles, B.M. (2011) Concepts and Formation of Relationships in Social Networks. RAD, 13, 157-169. https://doi.org/10.20946/rad.v13i1.3451

[56] Bourdieu, P. (1986) The Forms of Capital. In: Richardson, J., Ed., Handbook of Theory and Research for the Sociology of Education, Greenwood, New York, 241-258.

[57] Ellison, N.B., Gray, R., Vitak, J., Lampe, C. and Fiore, A.T. (2013) Calling All Facebook Friends: Exploring Requests for Help on Facebook. In: Proceedings of the 7 th Annual International Conference on Weblogs and Social Media, Association for the Advancement of Artificial Intelligence, Washington DC, 155-164.

[58] Ellison, N.B., Gray, R., Lampe, C. and Fiore, A.T. (2014) Social Capital and Resource Requests on Facebook. New Media \& Society, 16, 1104-1121. https://doi.org/10.1177/1461444814543998

[59] Treuren, G. and Anderson, K. (2010) The Employment Expectations of Different Age Cohorts: Is Generation Y Really That Different? Australian Journal of Career Development, 19, 49-61. https://doi.org/10.1177/103841621001900207

[60] Rentz, K.C. (2015) Beyond the Generational Stereotypes: A Study of U.S. Generation Y Employees in Context. Business and Professional Communication Quarterly, 78, 136-166. https://doi.org/10.1177/2329490615576183

[61] McLuhan, M. (1964) Understanding Media: The Extensions of Man. McGraw-Hill, New York. 
[62] Foucault, M. (1995) Discipline and Punish: The Birth of the Prison. Vintage Books, New York

[63] Hermida, A. (2015) Power Plays on Social Media. Social Media + Society, 1, 1-2. https://doi.org/10.1177/2056305115580340

[64] Weng, L., Flammini, A., Vespignani, A. and Menczer, F. (2012) Competition among Memes in a World with Limited Attention. Scientific Reports, 2, Article No. 335. https://doi.org/10.1038/srep00335

[65] Romero, D.M., Galuba, W., Asur, S. and Huberman, B.A. (2011) Influence and Passivity in Social Media. In: Proceedings of the 20 th International Conference on World Wide Web, ACM, New York, 113-114. 